Document downloaded from:

http://hdl.handle.net/10251/149641

This paper must be cited as:

Schiop, ST.; Al Hassan, M.; Sestras, AF.; Boscaiu, M.; Sestras, RE.; Vicente, O. (2017). Biochemical responses to drought, at the seedling stage, of several Romanian Carpathian populations of Norway spruce (Picea abies L. Karst). Trees. 31(5):1479-1490. https://doi.org/10.1007/s00468-017-1563-1

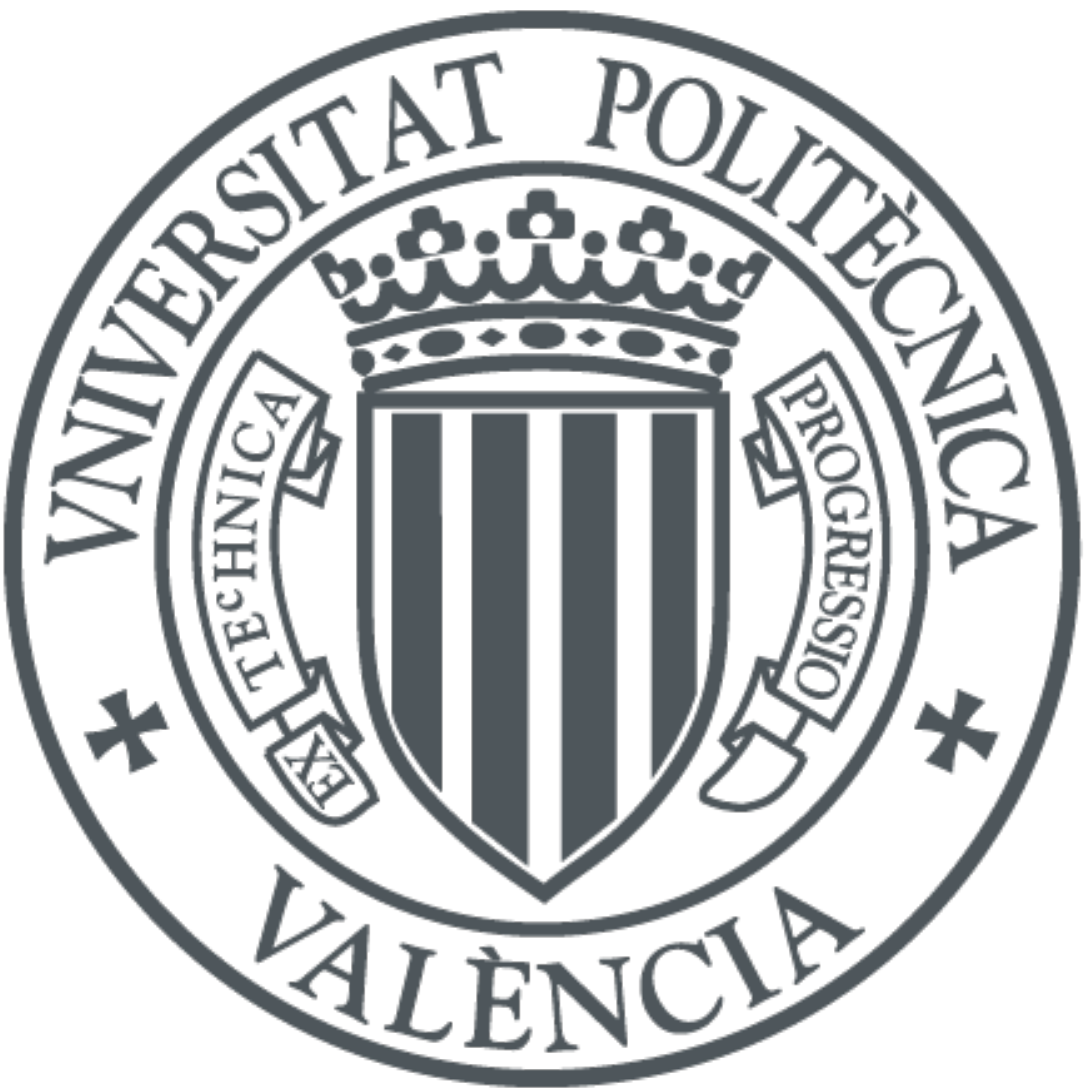

The final publication is available at

https://doi.org/10.1007/s00468-017-1563-1

Copyright Springer-Verlag

Additional Information 


\title{
Biochemical responses to drought, at the seedling stage, of several Romanian Carpathian populations of Norway spruce (Picea abies L. Karst)
}

\author{
Sorin T. Schiop ${ }^{1,2}$, Mohamad Al Hassan ${ }^{2,5}$, Adriana F. Sestras ${ }^{1}$, Monica Boscaiu ${ }^{3 *}$, Radu E. Sestras ${ }^{4}$, \\ Oscar Vicente ${ }^{2}$ \\ ${ }^{1}$ Department of Forestry, Faculty of Horticulture, University of Agricultural Sciences and Veterinary \\ Medicine, Cluj-Napoca, Romania \\ ${ }^{2}$ Institute of Plant Molecular and Cellular Biology (IBMCP, UPV-CSIC), Universitat Politècnica de València, \\ Valencia, Spain \\ ${ }^{3}$ Mediterranean Agroforest Institute (IAM, UPV), Universitat Politècnica de València, Valencia, Spain \\ ${ }^{4}$ Department of Horticulture and Landscaping, Faculty of Horticulture, University of Agricultural Sciences \\ and Veterinary Medicine, Cluj-Napoca, Romania \\ ${ }^{5}$ Present address: The New Zealand Institute for Plant \& Food Research Ltd., Auckland, New Zealand \\ * Corresponding author E-mail: mobosnea@eaf.upv.es; Telephone: +34963879253
}

Abstract. Norway spruce is a native European coniferous species distributed from the Carpathian Mountains and the Alps to northern Scandinavia. In the coming decades, spruce forests will need to cope with increasing climate changes which are already threatening their natural habitats. European forest policy should adapt to the changing climate by deploying drought-tolerant genotypes in regions expected to experience increased stress in the future. To identify reliable water stress biomarkers in this species, which may be eventually used to select populations responding better to forecasted drought events, we studied the physiological responses to severe water stress treatments of spruce seedlings originating from several locations in the Romanian Carpathian Mountains. Oneyear old seedlings were denied irrigation for six weeks in order to generate severe water stress in controlled conditions. Variations in the levels of the studied photosynthetic pigments, osmolytes, and non-enzymatic antioxidants were detected across the spruce populations. Several of the determined parameters in seedling needles, such as the decrease in water content (nearly $40 \%$ decrement in the most sensitive studied populations), the degradation of chlorophylls, or a low increase of proline levels (up to seven-fold increment in the most sensitive populations in comparison to no change in the most tolerant ones), could be employed as biomarkers for an early assessment of water stress at this stage. Furthermore, seedlings from two of the populations under study (Sudrigiu and Gioristea-Calimanut) apparently responded better to water stress than the other populations, as shown by their lower reduction in needle water content, no degradation of chlorophyll $a$ and carotenoids, and less proline accumulation, suggesting a relatively higher 
37 resistance to drought. These populations also seemed to be the least affected by osmotic stress at the

38 seed germination stage. Therefore, we consider that the use of biochemical markers of stress at

39 early seedling stages could represent a useful tool for the initial screening of populations that have

40 relatively high tolerance to drought, warranting further research for potential use in reforestation.

41

42 Keywords: Biomarkers, drought, Norway spruce, reforestation, seedlings.

43

44 Key Message: Norway spruce seedlings apparently showing a relatively higher tolerance to drought 45 can be easily selected using a battery of biomarkers such as water content, chlorophyll and proline 46 levels in the needles, and could be eventually used as initial screening method in reforestation 47 programmes.

48

49 Aknowledgments: This work was partly carried out under the frame of the European Social Fund, 50 Human Resources Development Operational Programme 2007-2013, project no. 51 POSDRU/159/1.5/S/132765.

52 We thank o the two unknown reviewers for their useful comments that considerably improved the 53 manuscript. 
55 Authors Contributions: The experiments were designed and conceived by STS, MAH, MB and $56 \mathrm{OV}$, and performed by STS and MAH. All authors contributed to the analysis of the results, the 57 statistical treatment of the data and the preparation of the manuscript. OV was responsible for the 58 general supervision of the work. The reagents and materials used to carry out the experimental work 59 were contributed by $\mathrm{MB}$ and $\mathrm{OV}$.

60

61 Whereby,

62 Sorin T. Schiop: STS

63 Mohamad Al Hassan: MAH

64 Adriana F. Sestras: AFS

65 MonicaBoscaiu: MB

66 Radu E. Sestras: RES

67 Oscar Vicente: OV

68

69 Conflict of Interests: The authors declare no conflict of interests. 


\section{Introduction}

71 Norway spruce is a native European coniferous species growing in large areas across north Scandinavia, the

72 Alps, and the Balkan and Carpathian Mountains (Mitchell 1972). It has an estimated geographical range of

73 approximately 30 million hectares, while at least 7 million hectares of pure spruce are located outside its

74 natural range (Jansson et al. 2013; Kazda 2005).

In the coming decades, the world's forest trees will need to cope with the increasing climate changes which are already threatening their natural habitats (Allen et al. 2010; Dale et al. 2001; Gilliam 2016). Consequently, new strategies and measures should be designed and implemented to minimise wood and environmental losses in the future. Europe's spruce reforestation policies should be based on the so-called 'adaptive forest management', a relatively recent concept regarding species survival and evolution (Lindner 2000). Active adaptation would be a suitable management strategy for stand conversion, based on replacing sensitive populations or tree species with others which could potentially respond better to the forecasted climate changes during their life cycle (Bolte et al. 2009).

The distribution of Norway spruce has varied in time due to climate influence (Bradshaw et al. 2000). The deleterious effects of environmental stresses, especially drought, on growth rates and tree mortality have often been underestimated in the past (Spiecker 2000). The occurrence of previous drought periods has damaged spruce stand in terms of radial growth, particularly in areas outside its natural range, which are affected by lower precipitation levels (Kahle et al. 2005).

The Intergovernmental Panel on Climate Change (IPCC) climate predictions up to 2080 show that mean temperatures will increase on the continent by $1.4-4.5{ }^{\circ} \mathrm{C}$, with the largest differences occurring in the southern countries (EEA 2004). According to Cuculeanu et al. (2002), who analysed climate change in Romania until 2075 using different GCMs (General Circulation Models), air temperature in Romania will increase by $2.8-4.9^{\circ} \mathrm{C}$, depending on the model used, while precipitation will decrease by $20 \%$. As reported by Lévesque (2013), Norway spruce populations from Central Europe are more vulnerable to soil water deficit than other conifers. The species will likely migrate to higher altitudes and to the north of Europe, with great area losses in the central part of the continent (Hanewinkel et al. 2013). Other studies confirm that spruce evaporative requirements are strongly related to the water supply of the stand, while drought sensitivity seems to be higher in altitudes below $1000 \mathrm{~m}$ (Maaten-Theunissen et al. 2013).

Spruce stands across Europe, including those in Romania, are likely to be affected by drought stress in the near future, with negative effects on growth rate and timber quality. Additional damage to the forest could involve lower rates of natural regeneration and reduced natural productivity, and possibly the disruption of its ecological balance and composition. The risk of infestation by insects and fungal diseases, such as spruce bark beetle or Armillaria spp., may weaken stand stability, causing more wind breakage events (Green and Ray 2009; Hart et al. 2014; Kolström et al. 2011). 
The most common drought effects include inhibition of photosynthesis due to reduction of photosynthetic pigment contents, stomatal oscillations, respiration and oxidative damage (Farooq et al. 2009;

106 Jaleel et al. 2009). Genetic approaches have shown that drought tolerance of plants relies on their capability 107 of activating adaptive mechanisms to counteract these deleterious effects, at physiological, biochemical and molecular levels (Kantar et al. 2011).

Spruce trees affected by drought show parallel biochemical and physiological changes leading to reductions in sap flow, in the rate of stem circumference increase, and in needle water potential (Ditmarová

111 et al. 2010; Ježík et al. 2014). At the cytological level, it has been observed that xylem cells have smaller

112 lumen and thicker walls, while the number of underdeveloped sclerenchyma cells increases (Kivimäenpää et 113 al. 2003; Montwe et al. 2014). Protective mechanisms in the first days of seedling exposure to drought 114 consist of an adjustment to low osmotic potential correlated with a decline in transpiration and activation of 115 nitrogen metabolism (Grossnickle 2000; Modrzynski 2007). Long term drought leads to hydraulic failure and 116 carbon starvation, and eventually to tree mortality (McDowell et al. 2008).

117 As a response to the forecasted effects of climate change, the 'European Information System on 118 Forest Genetic Resources' has established 363 gene conservation units and 202 seed stands across 14 119 European countries (EUFGIS 2011). Romania ranks in the second position, with 84 seed units which are used 120 in the country's reforestation programmes. These seed stands should be suitable for the specific local 121 environmental conditions. However, large areas of the country's Norway spruce stands have been affected by 122 drought, and it is necessary to consider an adaptive management approach for spruce reforestation.

123 Reforestation programmes in Europe are using spruce seedlings with origin in the certified seed stand 124 mentioned above. Yet forestry practices should take into consideration alternative solutions to minimise stand 125 losses and environmental damage. A selection of European spruce populations with higher drought tolerance 126 127 stress.

128 The effects of abiotic stress, including drought, are generally assessed by measuring the degree of inhibition of plant growth. Faced with a situation of stress, plants divert resources (energy, metabolic precursors) from normal metabolism and biomass accumulation, to the activation of defence mechanisms,

131 which causes the arrest or drastic reduction of growth (Munns and Termaat 1986; Zhu 2001). However, in 132 species of slow growth, like spruce and most forest tress, very long treatments would be required to observe 133 significant stress-induced changes in growth parameters. The definition of specific, easy to quantify, 134 physiological and biochemical markers associated with drought, should allow an initial, rapid analysis of the 135 responses of the plants to the stress treatment. Appropriate biomarkers are likely to include those involved in 136 conserved responses to water stress: a decrease in leaf water content, degradation of photosynthetic pigments, 137 the accumulation of specific osmolytes, or the activation of antioxidant systems, changes that have been 138 associated to abiotic stress-induced inhibition of growth in many different woody species (e.g., Jiménez et al. 139 2013; Popović et al. 2016; Zrig et al. 2015), including conifers (Guo et al. 2010; Schiop et al. 2015;

140 Sudachkova et al. 2002). 
The major aim of this work was to identify suitable biochemical markers associated with drought in

142 Picea abies seedlings, which could be used for the rapid analysis of responses to controlled water stress

143 treatments. Several Norway spruce populations, located at different altitudes along the Romanian Carpathian

144 Mountains, were selected for these experiments. Seedlings, obtained by germination of seeds with an

145 established origin, were grown in the greenhouse before being subjected to water stress treatments. In

146 complementary experiments, seeds from the same stocks were independently germinated in vitro under

147 conditions of osmotic stress - to mimic the drought treatment. By performing a comparative analysis of the

148 responses of different spruce populations, the study also aimed at developing a tool based on combination of

149 several biochemical markers that could be used for a preliminary e selection of the populations that better

150 respond to water stress at early seedling stage.

151

152 2. Materials and Methods

153

Seedling origin, growth conditions and water stress treatments

155

156

157

158

159

160

161

162

163

164

165

166
Descendants from seven Romanian spruce populations, included in the National Catalogues of Forest Genetic Resources and Seed Reservations, were grown in a greenhouse located in Albac, Romania, during one complete vegetation season (the origins of the genetic resources and climatic data are indicated in Tab. 1). The seeds were sown during April under appropriate conditions of temperature and high humidity of air and soil. Prior to sowing, the seeds were subjected to a pre-germination treatment, keeping them in cold water for 48 hours, as described by Radu et al. (1994). The seedlings were grown on peat substrate collected from a site in the Vladeasa Mountains, Romania, near the place known as Padis (46.60415 N, 22.69618 E).

Tab. 1 Climatic data in the regions of origin of the seven studied P. abies populations, according to the National Meteorological Administration (NMA), Romania (Schiop et al. 2015)

\begin{tabular}{|c|c|c|c|c|c|c|}
\hline Identification & Population & $\begin{array}{l}\text { Geographic } \\
\text { coordinates }\end{array}$ & $\begin{array}{l}\text { Altitude } \\
\text { (m.a.s.1.) }\end{array}$ & $\begin{array}{c}\text { Mean annual } \\
\text { Temperature } \\
\left({ }^{\circ} \mathrm{C}\right)\end{array}$ & $\begin{array}{c}\text { Mean annual } \\
\text { Precipitation } \\
\quad(\mathrm{mm})\end{array}$ & $\begin{array}{c}\text { Mean } \\
\text { potential } \\
\text { PET }(\mathrm{mm})\end{array}$ \\
\hline GC & $\begin{array}{l}\text { Gioristea- } \\
\text { Calimanut }\end{array}$ & $\begin{array}{c}46^{\circ} 45^{\prime} \mathrm{N} / \\
25^{\circ} 20^{\prime} \mathrm{E}\end{array}$ & $840-1200$ & 6.4 & 642.0 & 558.5 \\
\hline VM & Valea Mare & $\begin{array}{c}46^{\circ} 28^{\prime} \mathrm{N} / \\
23^{\circ} 09^{\prime} \mathrm{E}\end{array}$ & $1200-1450$ & 5.6 & 893.0 & 517.3 \\
\hline $\mathrm{SD}$ & Sudrigiu & $\begin{array}{c}46^{\circ} 36^{\prime} \mathrm{N} / \\
22^{\circ} 25^{\prime} \mathrm{E}\end{array}$ & 230 & 10.4 & 751.9 & 672.6 \\
\hline $\mathrm{BM}$ & Basca Mica & $\begin{array}{c}45^{\circ} 45^{\prime} \mathrm{N} / \\
26^{\circ} 20^{\prime} \mathrm{E}\end{array}$ & $1250-1500$ & 1.9 & 800.7 & 428.6 \\
\hline $\mathrm{AB}$ & Albac & $\begin{array}{c}46^{\circ} 45^{\prime} \mathrm{N} / \\
22^{\circ} 97^{\prime} \mathrm{E}\end{array}$ & 770 & 7.8 & 837.6 & 594.0 \\
\hline PT & ParaulTurculet & $\begin{array}{c}47^{\circ} 44^{\prime} \mathrm{N} / \\
25^{\circ} 24^{\prime} \mathrm{E}\end{array}$ & $850-930$ & 7.2 & 707.8 & 607.3 \\
\hline
\end{tabular}




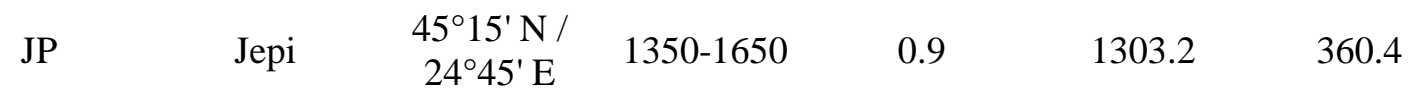

167

One-year-old seedlings were transplanted into pots with peat substrate during vegetative phase (blossom buds) and were transported to the greenhouse of the Institute of Plant Molecular and Cellular Biology (IBMCP), Polytechnic University of Valencia, Spain. Daily mean temperature during the 42 day-long experiment was $20{ }^{\circ} \mathrm{C}$, photoperiod 16 hours of light, humidity ranged between $60-70 \%$ and $\mathrm{CO}_{2}$ level was approximately 300 ppm. Control plants were watered twice a week using Hoagland's nutritive solution while drought treatment was performed by completely ceasing irrigation. After 42 days of treatment, water-stressed and control seedlings were harvested and several physiological and biochemical traits were determined in the needles.

Osmotic stress treatments at the seed germination stage

Seeds from the same seven stocks used to grow the spruce seedlings, were germinated in vitro, in the presence of increasing concentrations of polyethylene glycol 6000 (PEG-6000). Petri dishes (diameter: $9 \mathrm{~cm}$ ) were prepared with a sterile cotton base below a double layer of sterile filter paper, and $40 \mathrm{~mL}$ of water (for the control seeds) or $40 \mathrm{~mL}$ of aqueous PEG-6000 solutions generating osmotic pressures of $-0.13 \mathrm{MPa}$ (17.58 g/L), -0.26 MPa (30.12 g/L), or -0.52 MPa (49.37 g/L) were added to each dish. These osmotic pressures are the same produced by 30,60 and $120 \mathrm{mM} \mathrm{NaCl}$ solutions, respectively, and were calculated based on the Van't Hoff's equation (Ben-Gal et al. 2009).

Seeds were surface-sterilised in $15 \%(\mathrm{v} / \mathrm{v})$ hydrogen peroxide for one hour, then thoroughly rinsed with sterile water, and dried at room temperature. Sterilised seeds were placed on the surface of the filter paper in the Petri dishes, 30 seeds per dish, and the plates were sealed with parafilm. Three replicated Petri dishes (90 seeds in total) were used per spruce population and per treatment. Over a period of 21 days of germination, the plates were checked regularly (twice per week) and the number of germinated seeds was registered. At the end of the treatment, the seeds were scanned and the radicle, hypocotyl, and cotyledon lengths were measured using ImageJ software (Rasband 1997-2012). 'Mean germination time' (MGT) was calculated according to the formula: $\mathrm{MGT}=\Sigma \mathrm{Dn} / \Sigma \mathrm{n}$, where $\mathrm{n}$ represents the number of seeds germinated at day D, while D is the number of days from the beginning of germination (Ellis and Roberts 1981). Seedling vigour index (SVI) was calculated as: Germination percentage x [Mean root length (mm) + Mean hypocotyl length (mm)], as indicated by Abdul-Baki and Anderson (1973).

\section{Water content percentage}



(FW), and their dry weight (DW) - after drying the needles in an oven for 4 days at $65^{\circ} \mathrm{C}$ until constant

202 weight - using the formula: $\mathrm{WC} \%=[(\mathrm{FW}-\mathrm{DW}) / \mathrm{FW}] \times 100$.

Osmolyte levels

Free proline (Pro) in fresh needles was quantified according to the ninhydrin-acetic acid method of Bates et al. (1973). Pro was extracted in $2 \mathrm{~mL}$ of $3 \%$ aqueous sulfosalicylic acid; $1 \mathrm{~mL}$ of the extract was mixed with one volume of acid ninhydrin and one volume of glacial acetic acid, and incubated at $95{ }^{\circ} \mathrm{C}$ for 1 h. The sample was extracted with two volumes of toluene and absorbance of the organic phase was determined at $520 \mathrm{~nm}$, with toluene as a blank.

Total soluble sugars (TSS) in needles were measured according to the method of Dubois et al. (1956): ground dry material was suspended in $80 \%$ methanol and the sample was mixed in a shaker overnight. Concentrated sulphuric acid and $5 \%$ phenol was added and the absorbance of the solution at 490 $\mathrm{nm}$ was measured.

Non-enzymatic anti-oxidants

Total phenolic compounds (TPC) and 'total flavonoids' (TF) were measured in the same methanol extracts used for TSS determination. TPC were quantified by measuring the absorbance at $765 \mathrm{~nm}$ after reaction with the Folin-Ciocalteu reagent, according to Blainski et al. (2013), and expressed as equivalents of gallic acid (mg eq GA g ${ }^{-1} \mathrm{DW}$ ), used to obtain the standard curve. TF were measured following the procedure described by Zhishen et al. (1999), based on the nitration of aromatic rings bearing a catechol group and their reaction with $\mathrm{AlCl}_{3}$; this method detects antioxidant flavonoids but also other phenolics containing a catechol group. After the reaction, the absorbance of the sample was measured at $510 \mathrm{~nm}$, and the amount of flavonoids was expressed in catechin equivalents (mg eq. Catec. $\mathrm{g}^{-1} \mathrm{DW}$ ).

\section{Photosynthetic pigments}

Photosynthetic pigments (chlorophyll $a$, chlorophyll $b$ and total carotenoids) were measured according to the method of Lichtenthaler and Welburn (1983). The extraction was carried out in $80 \%$ cold acetone and optical density was read at $663 \mathrm{~nm}, 646 \mathrm{~nm}$ and $470 \mathrm{~nm}$. The values were expressed in $\mu \mathrm{g} / \mathrm{ml}$ and then transformed to $\mu \mathrm{g} / \mathrm{g}$ DW using the following formulas: 
Statistical analysis

239

Statistical analysis of the data was performed using Statgraphics Centurion XVI software (Statpoint Technologies, Inc.; Warrenton, Virginia, USA). The assumption of normality was checked by Shapiro-Wilk $\mathrm{W}$ test and the homogeneity of variance by the Levene test. One-way ANOVA was performed to compare the statistical significance of the difference among treatments at confidence level of $95 \%$. When the ANOVA null hypothesis was rejected, post-hoc comparisons were performed using the t-test (for seedling experiments) and the Tukey HSD test (for in vitro germination assays). All means throughout the text include the standard deviation $(\mathrm{SD})$

\section{Results}

Seed germination assays

Osmotic stress caused a general reduction in the percentage of seeds germinated after three weeks of treatment, but with clear quantitative differences between the different populations (Fig. 1). Concerning germination (in water) of control seeds, spruce populations could be divided in two groups: the first one (Valea Mare, Albac, and Paraul Turculet) showed high germination percentages, over $85 \%$, while in the second one, including the remaining populations, seed germination ranged between $40 \%$ and $50 \%$. The relative resistance to PEG-6000 of seeds from the different populations did not correspond to germination rates in the control. Under the strongest osmotic stress tested (-0.52 MPa), seeds from the Gioristea-Calimanut and Sudrigiu populations showed the smallest relative inhibition of germination; in GC seeds, in fact, differences in germination percentages were not statistically significant. On the other hand, seeds from Valea Mare and Paraul Turculet were the most affected by PEG-induced osmotic stress (Fig. 1).

Fig. 1 Germination rates of seeds from the seven analysed Picea abies populations (identification codes as in Tab. 1), after three weeks of osmotic stress treatments; the indicated osmotic pressures were generated by increasing PEG-6000 concentrations. Values are means with SD $(n=3)$. Different lowercase letters in a column indicate significant differences in germination rates between treatments, for each population. 
Different capital letters in a row indicate significant differences in germination rates between populations for each treatment according to the Tukey test $(\alpha=0.05)$

Osmotic stress also affected germination time in seeds from most populations, albeit only slightly. Considering the calculated average values, mean germination time (MGT) generally increased with increasing osmotic stress, but the differences between control and osmotic-stressed seeds were not statistically significant for populations Gioristea-Calimanut, Paraul Turculet and Jepi (Fig. 2).

Fig. 2 'Mean germination time' (MGT) of seeds from the seven analysed Picea abies populations (identification codes as in Tab. 1), after three weeks of osmotic stress treatments; the indicated osmotic pressures were generated by increasing PEG-6000 concentrations. Values are means with SD $(n=3)$. Different lowercase letters in a column indicate significant differences in MGT between treatments, for each population. Different capital letters in a row indicate significant differences in MGT between populations for each treatment according to the Tukey test $(\alpha=0.05)$

Finally, the 'seedling vigour index' was calculated for all populations and treatments (Fig. 3). Large differences between populations were found for control seeds germinating in water, but in all cases a decrease in SVI values was observed in the presence of PEG-6000, except for the Sudrigiu population, where the SVI remained practically constant. The populations most affected by osmotic stress during seed germination, according to the relative decrease of SVI values, were Valea Mare and Basca Mica (Fig. 3).

Summarising, seeds from the Sudrigiu and Gioristea-Calimanut populations showed the smallest decrease of germination percentages and were amongst those with no or only a small increase in MGT. On the other hand, seeds from Valea Mare and Paraul Turculet seemed to be the most affected by PEG-6000. It is interesting to note that the Sudrigiu seeds, apparently the most resistant to osmotic stress, are also those showing the lowest germination rate (40\%) and SVI (845), and the highest MGT (14.8 days) of all tested populations (Figs. 1, 2 and 3), in the control; that is, under non-stress conditions.

Fig. 3 'Seedling vigour index' (SVI) of seeds from the seven analysed Picea abies populations (identification codes as in Tab. 1), after three weeks of osmotic stress treatments; the indicated osmotic pressures were generated by increasing PEG-6000 concentrations

\section{Water content percentage in water-stressed Picea abies seedlings}

Water content in the needles of control seedlings ranged between 63 and $72 \%$, without significant differences among the analysed spruce populations, except when comparing those from Jepi and GioristeaCalimanut, which showed the highest and lowest values, respectively (Fig. 4).Water stress caused a significant decrease in water content in all populations, but seedling dehydration was not uniform. The largest differences within single populations were recorded in the Albac (3.7-fold), Jepi (3.5-fold) and Paraul 
Turculet (2.7-fold) samples, while the smallest were observed in the populations from Sudrigiu (1.3-fold) and Gioristea- Calimanut (1.4-fold). Therefore, the spruce seedlings from Sudrigiu appeared to be the most resistant to drought-induced dehydration, followed by GC.

Fig. 4 Water content (\%) in needles of Picea abies seedlings of the seven studied populations after 42 days of water stress treatments. Population identification codes are those defined in Tab. 1. Values shown are means with SD (n=3). Significant differences between populations are indicated by different lowercase Latin letters (for non-stressed control plants) or by different Greek letters (for drought-stressed plants) over the bars, while an asterisk $(*)$ shows significant differences in needle water content between control and water-stressed seedlings within each population, according to the t-test $(\alpha=0.05)$

\section{Chlorophyll a, chlorophyll $b$ and total carotenoids contents}

Needle contents of chlorophyll $a$, chlorophyll $b$, and total carotenoids were determined in seedlings of all $P$. abies populations, in control and drought-stressed plants. In control plants, mean chlorophyll $a$ levels in the Basca Mica and Albac populations were significantly lower than those measured in seedlings from Sudrigiu and Paraul Turculet, and intermediate values were determined in the other populations. Water stress treatments induced significant reductions of chlorophyll $a$ contents in the Valea Mare, Albac, Paraul Turculet and Jepi populations - the latter showing the largest decrease, by more than $40 \%$ relative to the control. Nonsignificant changes were observed in the Basca Mica population, and small, but significant, increases in chlorophyll $a$ levels were determined in the remaining two provenances, Gioristea-Calimanut and Sudrigiu (Fig. 5a).

Absolute chlorophyll $b$ contents were lower, about half of those of chlorophyll $a$, but the general patterns of variation between populations and the changes induced by water stress within each population, were similar, except that Jepi seedlings showed a smaller reduction, of $23 \%$ relative to the control, as compared to that observed for chlorophyll $a$ (Fig. 5b).

Total carotenoids did not differ significantly between populations in control seedlings. However, drought-induced changes in the concentration of these pigments varied in the different spruce populations; significant increases were measured in Gioristea-Calimanut and Sudrigiu, significant decreases in Albac and Jepi, and no significant variation in the other three populations (Fig. 5c).

Fig. 5 Chlorophyll $a$, chlorophyll $b$ and total carotenoids contents in needles of Picea abies populations after 42 days of water stress treatments. Population identification codes as defined in Tab. 1. Values shown are means with SD $(n=3)$. Significant differences between populations are indicated by different lowercase Latin letters (for non-stressed control plants) or by Greek letters (for drought-stressed plants) over the bars, while an asterisk $(*)$ shows significant differences in needle pigment content between control and water-stressed seedlings within each population, according to the t-test $(\alpha=0.05)$ 
Proline levels in control seedlings varied significantly between populations, in the range of 8 to 30

$\mu \mathrm{mol} \mathrm{g}{ }^{-1} \mathrm{DW}$, and increased in all cases in response to the drought treatment (Fig. 6a). The largest relative Pro accumulation in relation to the control (8-fold) was observed in Valea Mare seedlings. Spruce plants with origin in Basca Mica, Jepi, Albac and Paraul Turculet showed drought-dependent increases in Pro contents between 3- and 4-fold, while Pro concentration changed very little in Gioristea-Calimanut and Sudrigiu populations (Fig. 6a).

Total soluble sugars did not vary between populations, as compared to Pro levels. According to TSS contents in control seedlings, the seven studied populations could be separated in two groups without significant differences within each group: Albac, Paraul Turculet and Jepi, with TSS ranging between 45 and $47 \mathrm{mg}$ eq. glucose $\mathrm{g}^{-1} \mathrm{DW}$, on the one hand; and Gioristea-Calimanut, Valea Mare, Sudrigiu and Basca Mica (60-65 mg eq. glucose $\mathrm{g}^{-1} \mathrm{DW}$ ), on the other. TSS levels increased in all populations in response to water stress, but only slightly, not even doubling. The largest differences were measured in Paraul Turculet (65\% increase) and Jepi (45\%) populations, while in Gioristea-Calimanut and Albac seedlings the differences were not statistically significant; TSS increases of $10 \%$ to $30 \%$ were observed for the remaining provenances (Fig. 6b). It should be noted that there was no correlation between the relative changes in Pro and TSS concentrations.

Fig. 6 Changes in proline (Pro) and total soluble sugars (TSS) contents in needles of Picea abies seedlings after 42 days of water stress treatments. Population identification codes as defined in Tab. 1. Values shown are means with SD $(n=3)$. Significant differences between populations are indicated by different lowercase Latin letters (for non-stressed control plants) or by Greek letters (for drought-stressed plants) over the bars, while an asterisk (*) shows significant differences in needle osmolyte content between control and waterstressed seedlings within each population, according to the t-test $(\alpha=0.05)$

\section{Total phenolic compounds and flavonoids}

Total phenolic compounds and total flavonoid levels were relatively uniform in control seedlings of most populations, ranging between 10 and $15 \mathrm{mg}$ eq. GA g ${ }^{-1} \mathrm{DW}$, approximately, for TPC (Fig. 7a) or 378 between 8 and $12 \mathrm{mg}$ eq. $\mathrm{C} \mathrm{g}^{-1} \mathrm{DW}$ for TF (Fig. 7b). The exception was the Jepi population for which lower contents of TPC (ca. $7 \mathrm{mg}$ eq. GA g ${ }^{-1} \mathrm{DW}$ ) and TF (4.4 mg eq. $\mathrm{C} \mathrm{g}^{-1} \mathrm{DW}$ ) were determined. These values generally increased in needles of water-stressed spruce seedlings, but quantitative differences varied between populations (Fig.7). The highest relative increases in TPC and TF were observed in Jepi seedlings (2.3-fold and 3.5-fold, respectively), followed by Paraul Turculet and Albac, and also Valea Mare in the case of TF (between 1.4 and 1.7-fold increases). Smaller stress-induced accumulation of antioxidant phenolics, or no 
patterns of variation of TPC and TF were similar, as should be expected since flavonoids represent the largest subgroup of phenolic compounds.

Fig. 7 Changes in total phenolic compounds (TPC) and total flavonoids (TF) in needles of Picea abies populations after 42 days of water stress treatments. Population identification codes as defined in Tab. 1. Values shown are means with SD $(\mathrm{n}=3)$. Significant differences between populations are indicated by different lowercase Latin letters (for non-stressed control plants) or by Greek letters (for drought-stressed plants) over the bars, while an asterisk (*) shows significant differences in needle TPC or TF content between control and water-stressed seedlings within each population, according to the t-test $(\alpha=0.05)$

\section{Discussion}

Drought is a major abiotic stress, with complex effects on plants, inducing a wide range of physiological and biochemical responses which can lead to growth inhibition and, eventually, plant death (Farooq et al. 2009; Harb et al. 2010). Early diagnosis of drought in plants is of critical importance to minimise deleterious effects, as morphological responses to different types of abiotic stress are similar and symptoms specific for water stress are often not easily recognised. In addition, in species of slow growth, such as forest trees, measurable inhibition of growth - which is generally the easiest to detect effect of drought and other abiotic stresses - requires long treatment periods.

Climate change scenarios predicted for the next decades will cause a higher exposure of spruce stands to adverse drought conditions, leading to increasing forest stress and mortality (Walker et al. 2015). In the present study drought-induced changes in the levels of several metabolites - which could be employed as biochemical stress markers - have been quantified in needles of spruce seedlings of seven different provenances, subjected to a short, but severe water stress treatment in the greenhouse. As it is well established in many other plant species (Bartels and Sunkar 2005), the general responses to water stress in spruce seedlings included, among others, a decrease in the needles water content, a decrease in chlorophyll $a$ and $b$ levels, accumulation of osmolytes such as proline and soluble sugars, and an increase in the contents of some non-enzymatic antioxidants, namely total phenolic compounds and flavonoids. The identification of suitable drought stress markers in this species would help in the initial screening of more tolerant populations, but further longer -time experiments are still when extrapolating such results to forest management programmes. Another aspect that should be taken into consideration is that greenhouse conditions do not overlap with natural conditions of forest stands. For instance in this study $\mathrm{CO}_{2}$ concentration is around $100 \mathrm{ppm}$ under the present conditions (Earth's $\mathrm{CO}_{2}$ Home Page) and therefore such results obtained should be reinforced with outdoor experiments in order to guide adaptive management and tree improvement.

Drought causes cellular dehydration in plants (Hoekstra et al. 2001; Morgan 1984; Toldi et al. 2009), and there are many publications reporting the loss of water in the leaves of different species, in response to water stress (e.g., Munné-Bosch and Peñuelas 2004; Saura-Mas and Lloret 2007; Yang et al. 2010). Changes 
422

423

424

425

426

427

428

429

430

431

432

433

434

435

436

437

438

439

440

441

442

443

444

445

446

447

448

449

450

451

452

453

454

455

456

457

458

in spruce water content have been previously investigated in trees of different ages and in different tissues, showing large variations in phloem water content but not so big differences in heartwood water (Gall et al. 2002; Kravka et al. 1999). Drought damages are observed mostly in spruce seedlings and young trees; the physiological processes triggered by water stress include a drop in tissue water and stomata closure, with the subsequent inhibition of photosynthesis, changes that become irreversible above a water deficit of $33 \%$ (Mejnartowicz and Lewandowski 2007). The response of white spruce [Picea glauca (Moench) Voss] or black spruce [Picea mariana (Mill) B.S.P.] seedlings to water stress treatments indicated a significant reduction in water content, even after a drought period shorter than that used in the present study (Marshall et al. 2000); this suggests that water content or, more specifically, the decrease in water content, can be considered as a suitable physiological water stress marker in this genus. Yet, while a drop of water content in the needles of $P$. abies seedlings was observed in all analysed populations, some of them were clearly less affected, such as those from Gioristea-Calimanut and, especially, from Sudrigiu. The capacity to reduce drought-induced needle dehydration could provide an indication of the relative degree of drought tolerance of the investigated populations, at least at the seedling stage.

A decrease in the levels of photosynthetic pigments due to drought is a common physiological response in many plant species (Al Hassan et al. 2017; Lei et al. 2006), including conifers (Alonso et al. 2001; Miron and Sumalan 2015) The observed effects of water stress on spruce seedlings pointed to a slight reduction in photosynthetic activity in stressed seedlings, due to a general degradation of chlorophyll $a$ and chlorophyll $b$. Yet some populations appeared to be less affected than the rest to degradation of photosynthetic pigments under drought conditions including, here again, spruce seedlings derived from Gioristea-Calimanut and Sudrigiu.

Proline (Pro) accumulation in plants in response to water deficit is a quite general phenomenon, which has been previously reported in many taxa, including conifers; in some species, the relative increase in Pro levels in relation to the non-stressed control can reach 100-fold or even more (Al Hassan et al. 2016a, d; Cyr et al. 1990; Heuer 2010; Pardo-Domènech et al. 2015; Patel and Vora 1985;). As in other studies, a significant increase of Pro in Norway spruce seedlings was reported after a short time of severe water stress treatments (Ditmarová et al. 2010), highlighting the potential of measuring drought-induced changes in Pro contents well before any growth inhibition can be detected in this slow-growing species. Yet there is not a clear, general correlation of Pro levels with the degree of stress tolerance, which varies widely in different taxa. Previous comparative studies have established a positive correlation between drought tolerance and Pro accumulation in some species (Jiménez et al. 2013; Lei et al. 2006), whereas in others this correlation is negative (Al Hassan et al. 2016c; Silvente et al. 2012) or no correlation could be found (e.g. Bhaskaran et al. 1985). This means that Pro can either be directly involved in the mechanisms of drought tolerance or simply act as an indicator of the level of stress affecting the plants. In P. abies, the latter possibility seems to apply, since the lowest Pro accumulation under water stress conditions was observed in seedlings from the Sudrigiu population, which according to other biomarkers appears to be the less affected by drought, as discussed above. 
Soluble sugars are also common omolytes in plants, and it is known that they can also accumulate in needles, sapwood or inner bark as a response to the drought-induced lowering of the osmotic potential (Clancy et al. 1995). Moreover, numerous greenhouse studies in which plants are subjected to water stress treatments have revealed a significant increase of soluble sugars contents in leaves (Al Hassan et al. 2016b, c; Jiménez et al. 2013; Sudachkova et al. 2002; Tan et al. 1992). The same pattern has been observed in the present study, although the drought-induced increases in soluble sugars are relatively small. In addition, due to their multiple biological roles as direct products of photosynthesis, components of primary metabolism, precursors of other compounds and even signalling molecules, it is very difficult to assess the specific functions of soluble carbohydrates in the mechanisms of stress tolerance (see Gil et al. 2013, for a more extensive discussion on this topic). Therefore, total soluble sugars may not be reliable biochemical markers of drought stress in Norway spruce.

The activation of antioxidant systems, both enzymatic and non-enzymatic, is also a general response to drought and other abiotic stresses, which cause oxidative stress in plants as a secondary effect. Phenolic compounds and, within them, the subgroup of flavonoids contain strong antioxidant molecules; there is overwhelming evidence that these 'secondary metabolites' play a major role in the mechanisms of defence of plants against environmental stresses, including drought (Ramakrishna and Ravishanka 2011). In some populations of $P$. abies seedlings, total phenolics and antioxidant flavonoids increased significantly in response to water stress, as has been reported for many other species (e.g., Al Hassan et al. 2016a; Bautista et al. 2016; Hernández et al. 2004). However, this pattern was not uniform as some spruce populations including Gioristea-Calimanut and Sudrigiu - showed very small increases or non-significant changes in TPC and TF levels, suggesting that they could be relatively less affected by drought-induced oxidative stress.

Despite the variability in the patterns of physiological and biochemical parameters detected in the different $P$. abies populations, in response to water stress, the simultaneous assessment of several of these putative biomarkers could provide relevant information on the deleterious effects of drought on spruce seedlings, well before growth inhibition can be observed. In practice, the most reliable drought stress biomarkers in $P$. abies appear to be the water content, chlorophylls and proline levels in the needles. These parameters can be easily and rapidly determined, using simple methods that require small amounts of plant material.

The use of this battery of biomarkers clearly points to the spruce seedlings with origin in Sudrigiu, followed by those from Gioristea-Calimanut, as the most resistant to drought: lowest reduction in water content (i.e, highest resistance to drought-induced dehydration), no significant degradation of chlorophylls, and lowest proline accumulation. This conclusion is strongly supported by the results of complementary experiments in which seeds of the same stocks were germinated in vitro in the presence of PEG-6000. According to different parameters of germination, such as germination rates, mean germination time (MGT) and 'seedling vigour index' (SVI), these assays revealed that the same populations, Sudrigiu and GioristeaCalimanut, are also the most tolerant to osmotic stress during seed germination. 
The climatic characteristics of the geographical locations of these two spruce populations may explain a relatively higher drought tolerance. Sudrigiu is located at the lowest altitude of all selected

497 provenances $(230 \mathrm{~m})$, which correlated with the highest mean annual temperature and highest potential 498 evapotranspiration. Gioristea-Calimanut is located at higher altitude, and consequently has a lower mean annual temperature, but is the population affected by the lowest mean annual precipitation. Therefore, the slightly different responses to water stress of the Sudrigiu and Gioristea-Calimanut seedlings, as compared to

501 the rest, could be due to adaptation of the original trees to somewhat drier natural environments.

502 As mentioned above, the short water stress treatments applied did not allow detecting inhibition of seedling growth, and the association of the selected biomarkers with plant performance under stress has not been directly demonstrated - although it is clearly established for many other species. Therefore, the results

505 presented here should be confirmed and extended in future studies involving longer drought treatments and 506 determination of their effect on growth parameters. Moreover, we do not know yet whether these biomarkers 507 are also suitable to assess drought responses in older trees; this is likely, considering that seed germination 508 and early seedling growth are generally more sensitive to stress than later developmental stages, but 509 additional experiments will be required to confirm it. Suitable biochemical markers could be used for a rapid 510 initial screening of a large number of individuals from different populations, but other functional traits, such 511 as rate of growth or productivity should be taken also in consideration in the selection of the optimal 512 genotypes in reforestation programmes.

\subsection{ReReferences}

516 Abdul-Baki AA, Anderson JD (1973) Relationship between decarboxilation of glutamic acid and vigour in 517 soybean seed. Crop Sci 13:222-226

518 Al Hassan M, Chaura J, López-Gresa MP, Borsai O, Daniso E, Donat-Torres MP, Mayoral O, Vicente O, 519 Boscaiu M (2016a) Native-invasive plants vs. halophytes in Mediterranean salt marshes: Stress tolerance 520 mechanisms in two related species. Front Plant Sci 7:473. doi:10.3389/fpls.2016.00473

521 Al Hassan M, Chaura J, Donat-Torres MP, Boscaiu M, Vicente O (2017) Antioxidant responses under salinity 522 and drought in three closely related wild monocots with different ecological optima. AoB PLANTS 9 523 (2):plx009. doi: 10.1093/aobpla/plx009

524 Al Hassan M, López-Gresa MP, Boscaiu M, Vicente O (2016b) Stress tolerance mechanisms in Juncus: 525 Responses to salinity and drought in three Juncus species adapted to different natural environments. Funct 526 Plant Biol 43:949-960

527 Al Hassan M, Morosan M, López-Gresa MP, Prohens J, Vicente O, Boscaiu M (2016c) Salinity-induced 528 variation in biochemical markers provides insight into the mechanisms of salt tolerance in common 529 (Phaseolus vulgaris) and runner (P. coccineus) beans. Int J Mol Sci 17:1582. doi:10.3390/ijms17091582 
Al Hassan M, Pacurar A, López-Gresa MP, Donat-Torres MP, Llinares JV, Boscaiu M, Vicente O (2016d) Effects of salt stress on three ecologically distinct Plantago species. PLoS ONE 11(8):e0160236. doi:10.1371/journal.pone.0160236

Allen CD, Macalady AK, Chenchouni H, Bachelet D, McDowell N, Vennetier M, Kitzberger T, Rigling A, Breshears DD, Hogg EH, Gonzalez P, Fensham R, Zhang Z, Castro J, Demidova N, Lim J-H, Allard G, Running SW, Semerci A, Cobb N (2010) A global overview of drought and heat-induced tree mortality reveals emerging climate change risks for forests. For Ecol Manage 259:660-684. doi: 10.1016/j.foreco.2009.09.001

Alonso R, Elvira S, Castillo FJ, Gimeno BS (2001) Interactive effects of ozone and drought stress on pigments and activities of antioxidative enzymes in Pinus halepensis. Plant cell Environ 24:905-916

Bartels D, Sunkar T (2005) Drought and salt tolerance in plants. Crit Rev Plant Sci 24:23-58

Bates LS, Waldren RP, Teare LD (1973) Rapid determination of free proline for water-stress studies. Plant Soil 39:205-207. doi: 10.1007/BF00018060

Bautista I, Boscaiu M, Lidón A, Llinares JV, Lull C, Donat MP, Mayoral O, Vicente O (2016) Environmentally induced changes in antioxidant phenolic compounds levels in wild plants. Acta Physiol Plant 38:9. doi: 10.1007/s11738-015-2025-2

Ben-Gal A, Borochov-Neori H, Yermiyahu U, Shani U (2009) Is osmotic potential a more appropriate property than electrical conductivity for evaluating whole-plant response to salinity? Environ Exp Bot 65:232237

Bhaskaran S, Smith RH, Newton RJ (1985) Physiological changes in cultured Sorghum cells in response to induced water stress. Plant Physiol 79:266-269. doi:10.1104/pp.79.1.266

Blainski A, Lopes GC, de Mello JCP (2013) Application and analysis of the Folin Ciocalteu method for the determination of the total phenolic content from Limonium brasiliense L. Molecules 18:68526865.doi:10.3390/molecules 18066852

Bolte A, Ammer C, Löf M, Madsen P, Nabuurs GJ, Schall P, Spathelf P, Rock J (2009) Adaptive forest management in central Europe: Climate change impacts, strategies and integrative concept. Scand J For Res 24:473-482. doi:10.1080/02827580903418224

Bradshaw RHW, Holmqvist BH, Cowling SA, Sykes MT (2000) The effects of climate change on the distribution and management of Picea abies in southern Scandinavia. Can J For Res 30:1992-1998

Clancy KM, Wagner MR, Reich PB (1995) Ecophysiology and insect herbivory. In: Smith WK, Hinckley TM (eds.) Ecophysiology of coniferous forests. Academic Press, San Diego, pp 125-180

Cuculeanu V, Tuinea P, Bălteanu D (2002) Climate change impacts in Romania: Vulnerability and adaptation options. Geo Journal 57:203-209. doi:10.1023/B:GEJO.0000003613.15101.d9

Cyr DR, Buxton GF, Webb DP, Dumbroff EB (1990) Accumulation of free amino acids in the shoots and roots of three northern conifers during drought. Tree Physiol 6:293-303. doi:10.1093/treephys/6.3.293 
Dale VH, Joyce LA, McNulty S, Neilson RP, Ayres MP, Flannigan MD, Hanson PJ, Irland LC, Lugo AE, disturbances. BioSci 51:723-734

568

Ditmarová L, Kurjak D, Palmroth S, Kmet J, Strelcová K (2010) Physiological responses of Norway spruce (Picea abies) seedlings to drought stress. Tree Physiol 30:205-213. doi:10.1093/treephys/tpp116 Dubois M, Gilles KA, Hamilton JK, Rebers PA, Smith F (1956) Colorimetric method for determination of sugars and related substances. Anal Chem 28:350-356. doi:10.1021/ac60111a017

Earth's $\mathrm{CO}_{2}$ Home Page ??? How to cite

573 EEA (2004) Projected temperature changes in Europe up to 2080. www.eea.europa.eu. Accessed 16 August 5742016

575 Ellis RH, Roberts EH (1981) The quantification of aging and survival in orthodox seeds. Seed Sci Technol 576 9:373-409

577 EUFGIS (2011) Portal Gene reserve forests. European Commission under the Council Regulation (EC) No 870/2004. www.portal.eufgis.org. Accessed 17 January 2016

579 Farooq M, Wahid A, Kobayashi N, Fujita D, Basra SMA (2009) Plant drought stress: effects, mechanisms 580 and management. Agron Sustain Dev 29:185-212. doi:10.1051/agro:2008021

581 Gall R, Landolt W, Schleppi P, Michellod V, Bucher JB (2002) Water content and bark thickness of Norway spruce (Picea abies) stems: phloem water capacitance and xylem sap flow. Tree Physiol 22:613-623

583 Gil R, Boscaiu M, Lull C, Bautista I, Lidón A, Vicente O (2013) Are soluble carbohydrates ecologically

584 relevant for salt tolerance in halophytes? Funct Plant Biol 40:805-818

585 Gilliam FS (2016) Forest ecosystems of temperate climatic regions: from ancient use to climate change. New 586 Phytol 212:871-887. doi: 10.1111/nph.14255

587 Green S, Ray D (2009) Potential impacts of drought and disease on forestry in Scotland. Forestry 588 Commission Research Note. http://www.forestry.gov.uk/pdf/FCRN004.pdf/\$FILE/FCRN004.pdf. Accessed 589 29August 2016

590 Grossnickle SC (2000) Ecophysiology of northern spruce species: the performance of planted seedlings. NRC 591 Research Press, Ottawa

592 Guo J, Yang Y, Wang G, Yang L, Sun X (2010) Ecophysiological responses of Abies fabri seedlings to 593 drought stress and nitrogen supply. Physiol Plant 139:335-347

594 Hanewinkel M, Cullmann DA, Schelhaas MJ, Nabuurs GJ, Zimmermann NE (2013) Climate change may 595 cause severe loss in the economic value of European forest land. Nat Clim Change 3:203-207. 596 doi:10.1038/nclimate1687

597 Harb A, Krishnan A, Ambavaram MMR, Pereira A (2010) Molecular and physiological analysis of drought 598 stress in Arabidopsis reveals early responses leading to acclimation in plant growth. Plant Physiol 154:1254599 1271. doi: 10.1104/pp.110.161752 
Hart SJ, Veblen TT, Eisenhart KS, Jarvis D, Kulakowski D (2014) Drought induces spruce beetle

601 (Dendroctonus rufipennis) outbreaks across northwestern Colorado. Ecology 95:930-939. doi:10.1890/13-

$602 \quad 0230.1$

603 Hernández Y, Alegre L, Munné-Bosch S (2004) Drought-induced changes in flavonoids and other low

604 molecular weight antioxidants in Cistus clusii grown under Mediterranean field conditions. Tree Physiol 24

$605 \quad 1303-1311$

606 Heuer B (2010) Role of proline in plant response to drought and salinity. In: Pessarakli M (ed.) Handbook of

607 plant and crop stress. CRC Press, Boca Raton, pp 213-238

608 Hoekstra FA, Golovina EA, Buitink J (2001) Mechanisms of plant desiccation tolerance. Trends Plant Sci 609 6:431-438

610 Jaleel CA, Manivannan P, Wahid A, Farooq M, Al-Juburi HJ, Somasundaram R, Panneerselvam R (2009)

611 Drought stress in plants: a review on morphological characteristics and pigments composition. Int J Agric

612 Biol 11:100-105

613 Jansson G, Danusevicius D, Grotehusman H, Kowalczyk J, Krajmerova D, Skroppa T, Wolf H (2013)

614 Norway Spruce (Picea abies (L.) H. Karst. In: Pâques LE (ed) Forest Tree Breeding in Europe: Current State-

615 of-the Art and Perspectives. Springer, Dordrecht, pp 123-176

616 Ježík M, Blaženec M, Letts MG, Ditmarová L, Sitková Z, Střelcová K (2014) Assessing seasonal drought

617 stress response in Norway spruce (Picea abies(L.) Karst. by monitoring stem circumference and sap flow.

618 Ecohydrology. doi:10.1002/eco.1536

619 Jiménez S, Dridi J, Gutierrez D, Moret D, Irigoyen JJ, Moreno MA, Gogorcena Y (2013) Physiological,

620 biochemical and molecular responses in four Prunus rootstocks submitted to drought stress. Tree Physiol 33:

$621 \quad 1061-1075$

622 Kahle HP, Unseld R, Spiecker H (2005) Forest ecosystems in a changing environment: growth patterns as

623 indicators for stability of Norway spruce within and beyond the limits of its natural range. In: Bohn U,

624 Hettwer C, Gollub G (eds) Application and analysis of the map of the natural vegetation of Europe.

625 Bundesamt für Naturschutz, Bonn, pp 399-409

626 Kantar M, Lucas SJ, Budak H (2011) Drought stress: molecular genetics and genomics approaches. Adv Bot

627 Res 57:445-493

628 Kazda M (2005) Results from the SUSTMAN Project (EU Framework 5, QLK5-CT-2002-00851).

629 www.sustman.de. Accessed 30 August 2016

630 Kivimäenpää M, Sutinen S, Karlsson PE, Selldén G (2003) Cell structural changes in the needles of Norway

631 spruce exposed to long-term ozone and drought. Ann Bot 92:779-793. doi:10.1093/aob/mcg202

632 Kolström M, Lindner M, Vilén T, Maroschek M, Seidl R, Lexer MJ, Netherer S, Kremer A, Delzon S, Barbati

633 A, Marchetti M, Corona P (2011) Reviewing the science and implementation of climate change adaptation 634 measures in European forestry. Forests 2:961-982. doi:10.3390/f2040961

635 Kravka M, Krejzar T, Cermak J (1999) Water content in stem wood of large pine and spruce trees in natural 636 forests in central Sweden. Agric For Meteorol 98-99:555-562 
637 Lei Y, Yin C, Li C (2006) Differences in some morphological, physiological and biochemical responses to

638 drought stress in two contrasting populations of Populus przewalskii. Physiol Plant, 127:182-191

639 Lévesque M (2013) Drought response of five conifers along an ecological gradient in Central Europe: a

640 multiproxydendroecological analysis. Dissertation, ETH Zurich

641 Lichtenthaler HK, Wellburn AR (1983) Determinations of total carotenoids and chlorophylls $a$ and $b$ of leaf

642 extracts in different solvents. Biochem Soc Trans 11:591-592. doi: 10.1042/bst0110591

643 Lindner M (2000) Developing adaptive forest management strategies to cope with climate change. Tree

644 Physiol 20:299-307

645 Maaten-Theunissen M, Kahle HP, Maaten E (2013) Drought sensitivity of Norway spruce is higher than that

646 of silver fir along an altitudinal gradient in south western Germany. Ann For Sci 70:185-193. doi:

$647 \quad 10.1007 / \mathrm{s} 13595-012-0241-0$

648 Marshall JG, Rutledge RG, Blumwald E, Dumbroff EB (2000) Reduction in turgid water volume in jack pine,

649 white spruce and black spruce in response to drought and paclobutrazol. Tree Physiol 20:701-707

650 McDowell N, Pockman WT, Allen CD, Breshears DD, Cobb N, Kolb T, Plaut J, Sperry J, West A, Williams

651 DG, Yepez EA (2008) Mechanisms of plant survival and mortality during drought: why do some plants

652 survive while others succumb to drought? New Phytol 178:719-739. doi:10.1111/j.1469-8137.2008.02436.x

653 Mejnartowicz L, Lewandowski A (2007) Biochemical genetics. In: Mark GT, Adam B, Wladyslaw B (eds.)

654 Biology and ecology of Norway spruce. Forestry sciences, Springer, Dordrecht, pp 147-155

655 Miron MS, Sumalan RL (2015) Physiological responses of Norway spruce (Picea abies [L.] Karst) seedlings

656 to drought and overheating stress conditions. JHFB 19:146-151

657 Mitchell AF (1972) Conifers in the British Isles: A descriptive handbook. Forestry Commission Booklet No.

658 33, HMSO, LondonModrzynski J (2007) Ecology. In: Tjoelker MG, Boratynski A, Bugala W (eds.) Biology

659 and Ecology of Norway spruce. Springer, Dordrecht, pp 195-220

660 Montwe D, Spiecker H, Hamann A (2014) An experimentally controlled extreme drought in a Norway spruce

661 forest reveals fast hydraulic response and subsequent recovery of growth rates. Trees 28:891-900.

662 doi:10.1007/s00468-014-1002-5

663 Morgan JM (1984) Osmoregulation and water stress in higher plants. Ann Rev Plant Physiol 35:299-319

664 Munné-Bosch S, Peñuelas J (2004) Drought-induced oxidative stress in strawberry tree (Arbutus unedo L.)

665 growing in Mediterranean field conditions. Plant Sci 166:1105-1110

666 Munns R, Termaat A (1986) Whole-plant responses to salinity. Aust J Plant Physiol 13:143-160

667 Pardo-Domènech LL, Tifrea A, Grigore MN, Boscaiu M, Vicente O (2015) Proline and glycine betaine

668 accumulation in two succulent halophytes under natural and experimental conditions. Plant Biosyst 150:904-

669915

670 Patel JA, Vora AB (1985) Free proline accumulation in drought-stressed plants. Plant Soil 84:427-429.

671 doi:10.1007/BF02275480 
672 Popović M, Šuštar V, Gričar J, Štraus I, Torkar G, Kraigher H, de Marco A (2016) Identification of

673 environmental stress biomarkers in seedlings of European beech (Fagus sylvatica) and Scots pine (Pinus

674 sylvestris). Can J For Res 46: 58-66

675 Radu S, Contescu L, Herta I, Burza E, Rosca T (1994) Pepiniere- Metode şi procedee pentru cultura în

676 pepinieră a principalelor specii forestiere şi ornamentale. Institutul de Cercetări şi Amenajări Silvice,

677 Bucureşti

678 Ramakrishna A, Ravishankar GA (2011) Influence of abiotic stress signals on secondary metabolites in

679 plants. Plant Signal Behav 6:1720-1731. doi:10.4161/psb.6.11.17613

680 Rasband WS (1997-2012) ImageJ. U S National Institutes of Health. http://rsb.info.nih.gov/ij/. Bethesda,

681 Maryland

682 Saura-Mas S, Lloret F (2007) Leaf and shoot water content and leaf dry matter content of Mediterranean

683 woody species with different post-fire regenerative strategies. Ann Bot 99:545-554

684 http://doi.org/10.1093/aob/mcl284

685 Schiop ST, Al Hassan M, Sestras AF, Boscaiu M, Sestras RE, Vicente O (2015) Identification of salt stress

686 biomarkers in Romanian Carpathian populations of Picea abies (L.) Karst. PLoS ONE 10(8):e0135419.

687 doi:10.1371/journal.pone.0135419

688 Silvente S, Sobolev AP, Lara M (2012) Metabolite adjustments in drought tolerant and sensitive soybean

689 genotypes in response to water stress. PLoS ONE 7(6):e38554. doi: 10.1371/journal.pone.0038554

690 Spiecker H (2000) Growth of Norway spruce (Picea abies [L.] Karst.) under changing environmental

691 conditions in Europe. In: Klimo E, Hager H, Kulhavy J (eds.) Spruce monocultures in Central Europe-

692 problems and prospects. European Forest Institute Proceedings 33:11-26

693 Sudachkova NE, Milyutina IL, Semenova GP (2002) Influence of water deficit on contents of carbohydrates

694 and nitrogenous compounds in Pinus sylvestris L. and Larix sibirica Ledeb. tissues. Eurasian J For Res 4:1-11

695 Tan W, Blake TJ, Boyle TJB (1992) Drought tolerance in faster- and slower-growing black spruce (Picea

696 mariana) progenies: II. Osmotic adjustment and changes of soluble carbohydrates and amino acids under

697 osmotic stress. Physiol Plant 85:645-651. doi:10.1111/j.1399-3054.1992.tb04767.x

698 Toldi O, Tuba Z, Scott P (2009) Vegetative desiccation tolerance: Is it a goldmine for bioengineering crops?

699 Plant Sci 176:187-199. doi: 10.1016/j.plantsci.2008.10.002

700 Walker XJ, Mack MC, Johnstone JF (2015) Stable carbon isotope analysis reveals widespread drought stress

701 in boreal black spruce forests. Glob Chang Biol 21:3102-3113.doi: 10.1111/gcb.12893

702 Yang Y, Yao Y, Zhang X (2010) Comparison of growth and physiological responses to severe drought

703 between two altitudinal Hippophae rhamnoides populations. Silva Fenn 44:603-614

704 Zhishen J, Mengcheng T, Jianming W (1999) The determination of flavonoid contents in mulberry and their

705 scavenging effects on superoxide radicals. Food Chem 64:555-559

706 Zhu JK (2001) Plant salt tolerance. Trends Plant Sci 6:66-71 
707 Zrig A, Ben Mohamed H, Tounekti T, Ennajeh M, Valero D, Khemira H (2015) A comparative study of salt 708 tolerance of three almond rootstocks: contribution of organic and inorganic solutes to osmotic adjustment. J 709 Agr Sci Tech 17: 675-689

710 